\title{
Adoption of drought-tolerant rice in Thailand: Participatory varietal selection and implications for breeding programs
}

\author{
Orachos Napasintuwong ${ }^{1 *}$ and Carl Pray ${ }^{2}$ \\ ${ }^{1}$ Department of Agricultural and Resource Economics, Faculty of Economics, Kasetsart University, Bangkok, Thailand. \\ ${ }^{2}$ Department of Agricultural, Food, and Resource Economics, Rutgers: the State University of New Jersey, \\ New Brunswick USA.
}

Received 28 June, 2013; Accepted 16 July, 2014

\begin{abstract}
Rice production in Northeast Thailand has been suffering because of drought and limited irrigation. In this area, glutinous rice is generally produced for household consumption. The new drought-tolerant glutinous rice, RD12, developed to target drought-prone area in Northeast Thailand, was approved by the Rice Department in 2007. The breeding of this new variety has incorporated farmers' participation to identify preferred traits. This study aims to determine key factors contributing to the adoption of RD12 by focusing on farmers' preference for traits subjectively selected from the farmer participatory varietal selection (PVS) program. Key findings are that farmers who are exposed to more late-season drought because their fields are at higher elevations are more likely to adopt drought-tolerant varieties despite their preference for other better tasting varieties. Also, those who prefer the cooking characteristics of RD12 are more likely to adopt it, instead of the existing drought-tolerant variety. These two characteristics are significant for the adoption of RD12 and were identified as a result of PVS. This suggests that PVS is essential in the breeding program to promote new and appropriate technology to farmers.
\end{abstract}

Key words: Rice, drought tolerant, Thailand, adoption, participatory varietal selection, participatory breeding.

\section{INTRODUCTION}

Thailand is the sixth largest rice producer after China, India, Indonesia, Bangladesh, and Vietnam, and since the 1980s has been the largest exporter in the world market - until 2012 when it was surpassed by Vietnam and India. In spite of this, rice productivity in Thailand is the second lowest in Asia after Myanmar (International
Rice Research Institute, 2010).Insufficient water is one important reason for Thailand's low productivity, particularly in the Northeast which produces more than $40 \%$ of total rice production in the country and where more than $60 \%$ of the total area cultivated is in rice (Office of Agricultural Economics of Thailand, 2011).

*Corresponding author. E-mail: orachos.n@ku.ac.th, Tel: 662-579-8547 ext. 142. Fax: 662-942-8047.

Author(s) agree that this article remain permanently open access under the terms of the Creative Commons Attribution License 4.0 International License 
Northeast Thailand has the largest share of agricultural land and the largest number of farms. Due to salinity, low soil fertility and inadequate water infrastructure, this area is one of the least developed in the country's economy. Water storage and irrigation is a key production constraint in the Northeast Thailand. Despite investments in small, medium and large-scale irrigation systems (that is, dams, pumping stations, and irrigation) in the past sixty years, irrigation is concentrated on supplementary irrigation in the wet season and Northeast Thailand remains a predominantly rainfed area (Floch and Molle, 2007). Although rice can be produced two to three times a year, the majority of rice production in the Northeast is limited to the wet season (planting during May to October; harvesting during August to April) because of water accessibility during the dry season (planting during November to April; harvesting during February to October). With limited irrigation, farmers have to leave their land idle during the dry season. In 2010, 6.05 million hectares of rice were cultivated during the wet season in the Northeast compared to only about 0.48 million hectares during the dry season (Office of Agricultural Economics of Thailand, 2011).

Drought can adversely affect rice productivity at different times during the production cycle. In Northeast Thailand, it can occur both early, late and intermittently during the cropping season. Drought early in the cropping season causes a delay in rice transplanting and subsequently results in yield loss. It also increases the probability of late season yield loss from a delay in flowering. Yield loss during late-season drought, which develops at the end of the wet season before crop maturation is more severe than early-season drought. The estimates of yield reduction from late-season drought were 45 to $50 \%$ and 15 to $20 \%$ for the upper and middle top sequence, respectively (Jongdee, 2003). A twenty year simulation of yield loss in the Northeast showed that drought was more likely to develop in the latter stages of crop development; thus, high rainfall could still result in low yield if a drought occurs at a critical stage (Jongdee et al., 1997).

Prapertchob et al. (2007) found that during the late wet season, the upper Northeast has the lowest rainfall but the highest coefficient of variation. Although this zone was identified as low-risk of drought based on rainfall, hydrology and physical aspects of landscape according to Mongkolsawat et al. (2001), it is exposed to higher probability of yield and economic losses from late-season drought. Drought caused by climate change is expected to continue in the future and will have a significant impact on agriculture. The current impact of rainfall on agriculture based on the Generalized Monsoon Index shows that Northeast Thailand is experiencing severe drought, particularly in August and September (Thai Meteorological Department, 2012) when wet season crop planting occurs. Rainfall in Northeast Thailand has fluctuated in the past few decades and is expected to be lower by 2090 (Thai Meteorological Department, 2010). Adaptation strategies such as changing planting and harvesting time, switching to different cultivars and developing drought-tolerant crops were suggested as options (Asian Development Bank, 2009).

The Rice Department of Thailand successfully developed RD12, glutinous drought-tolerant rice suitable for the Northeast. It was approved by the Rice Department in March, 2007. Nongkhai province is the first area where RD12 has been disseminated. This province is bordered by Laos PDR to the North and by the Mekong River to the East. The mountains to the West cause intermittent and late droughts during the wet season. The climate in this area is dry during the planting time of the dry season (November to April) with the average rainfall of less than $100 \mathrm{~mm}$ and humid during the planting time of the wet season (May to October) with the average rainfall almost $300 \mathrm{~mm}$; however, rainfall drops dramatically in October to about $108 \mathrm{~mm}$ on average (Nongkhai Rice Research Center, 2013). Even though low fertility and coarse-textured and loamy sandy soils constrain production, weather especially variable rainfall distribution plays an important role in crop productivity and stability. Despite several large rivers, including the Mekong River, and small creeks and irrigation projects, less than $7 \%$ of agricultural land benefits from water management projects (Nongkhai Rice Research Center, 2013). Most farmers in this target drought-prone area are small farmers whose glutinous rice production is mainly for household consumption. Thus, preferences toward cooking characteristics are just as important as other traits.

Furthermore, as Prapertchob et al. (2007) found, farmers in this zone allocate their land to rice cultivation more than in other zones, but their yield and net returns from rice cultivation are the lowest. The development of drought-tolerant rice varieties for this target area will not only alleviate poverty, but also will ensure food security in the households. The breeding program of RD12 took into account farmer preferences by integrating participatory varietal selection (PVS) in the breeding process as a key determinant towards variety approval. Despite several released varieties, not all of them have been wellaccepted by farmers mainly due to the superiority of some traits of the existing varieties. RD12 is one of the first released varieties recommended for drought-prone areas. PVS is relatively new to the rice breeding program in Thailand. To date the impact of varieties developed using PVS has not been assessed. This paper aims to reveal whether the preferred traits of glutinous rice discovered by the PVS for rice breeding in drought-prone areas influence the adoption of the new variety. Specifically it seeks to identify factors affecting the adoption of RD12 by focusing on farmer preferences, particularly for early maturity and eating quality. 


\section{Participatory varietal selection for drought-tolerant rice}

Drought-tolerance traits can be classified into primary traits (such as, root depth), secondary traits (such as, leaf rolling), integrative traits, phenology (such as, flowering time) and plant-type traits (such as, plant height) (Kamoshita et al., 2008). Though simple, early flower genotype is often the most effective way of increasing yield under late-season drought (Kamoshita et al., 2008). Early flowering and early maturity varieties can escape from a late-season drought (Jongdee et al., 2006) which is a common problem for rice cultivation in Northeast Thailand. In non-irrigated areas, higher elevated paddies are likely to lose standing water earlier than those in lower positions. Thus earlier-flowering varieties would also reduce the risk of late-season drought and increase potential yield in drought-prone areas of the Northeast. Because glutinous rice is grown mainly for household consumption in upper Northeast Thailand, eating quality is likely as important as agronomic traits for farmers.

Despite the availability of recommended rice varieties for rainfed areas, the adoption of new varieties has had only partial success, to some extent due to the lack of traits important to farmers. Recently International Rice Research Institute (IRRI) recommended PVS be included as a standard part of all rainfed rice breeding programs (International Rice Research Institute, 2006). PVS trials are conducted on farms under the complete management of farmers; thus, it helps breeders and agronomists learn about the performance of new varieties under the real conditions faced by farmers and which varieties are preferred by them. In recognizing farmers' preferred traits, PVS has been increasingly implemented in several breeding programs (Bellon and Reeves, 2002; Ceccarelli and Grando, 2007; Doward et al., 2007; Efisue et al., 2008; Manzanilla et al., 2011; Morris and Bellon, 2004; Rasabandit et al., 2006; Witcombe et al., 1999; Wurzinger et al., 2011). Evidence shows that PVS improves the exposure to and adoption of new varieties (Diagne, 2006; Tshewang and Ghimiray, 2010; Witcombe et al., 1999); however, it has not been evident in the case of drought-tolerant glutinous rice in Thailand.

The "mother-baby" model was used in the breeding program of drought-tolerant rice in Thailand (Pantuwan et al., 2006; Jongdee et al., 2006) adopted from Snapp's technique (2002). The "mother" trial is replicated withinsite to test a range of varieties and research hypotheses under a breeder's management either located on a research station or on-farm. The "baby" trial comprises a number of satellite trials of large plots under farmers' management and farm resources. The objective of "mother" trials is to assess the agronomic characteristics of different lines designed and managed by breeders while the "baby" trials are designed by breeders and managed by farmers to elicit farmer perceptions. In this rainfed lowland rice breeding program, four hundred and seventy one field experiments were conducted in three provinces in the North and twelve provinces in the Northeast by selecting existing local varieties, existing modern varieties and promising lines from the breeding program for each location. Both upper toposequence position (upper paddy) and lower toposequence position (lower paddy) were selected for trials. In the mother trials, agronomic characteristics including yield, number of panicles, height, flowering days were analyzed, and the farmers vote for the variety they most preferred. In the baby trials, the experiment varieties were compared to farmers' own varieties based on agronomic characteristics. Grain characteristics (example, size, color) of both paddy rice and milled rice, and eating quality (example, softness, sweetness, and aromatic) of cooked rice were evaluated by farmers in both mother and baby trials.

Farmers' preference for agronomic characteristics revealed appropriate maturity matching with water conditions in paddies. Varieties with appropriate maturity (that is, early maturity for upper paddy), resistance to disease and insect pests, having good tillering with erectstrong stems, tall stature, similar level of height of panicles, droopy leaves and small number of leaves, big and long panicle, even panicle size, many grains per panicle, dense grains within panicle and long-slender grains are preferred. Furthermore, long slender and white grains are preferred while fragrance was farmers' preference, but not a strong requirement. PVS also showed that cooking and eating quality are the most important characteristics. Farmers could reject varieties preferred as paddy and milled rice if they dislike the cooking and eating qualities (Pantuwan et al., 2006).

RD12 is a cross between RD6 and Hahng Yi71. RD6, photoperiod-sensitive glutinous rice, has been wellpreferred in this area due to its supreme cooking quality and higher selling price. However, RD6 is susceptible to blast disease, especially when growing in the upper terrain. Hahng Yi71, photoperiod-sensitive early-maturity and blast-resistant glutinous rice has been commonly grown in upper terrain to avoid the risk of late-season drought (Saleeto et al., 2009).

Nevertheless, Hahng Yi71 has poor cooking quality and is not favored for consumption. The perceived advantageous traits of RD12 include early maturity, high yield and good milling; whereas, cooking quality is poorer than the popular RD6 (Jongdee et al., 2006). RD12 is resistant to blast and has earlier maturation than RD6; however, it is less resistant to drought than Hanhng Yi71. From the PVS in rainfed lowland rice breeding program discussed above, RD12 is recommended for rainfed areas in the Northeast, particularly in short rainy season or upper terrain area (Rice Department, 2009).

If the PVS were to improve the adoption of the new variety, Given the joint density of random vector 
$\varepsilon_{n}=\left(\varepsilon_{n 1}, \ldots, \varepsilon_{n J}\right)$,preferred traits (particularly early-maturity) would be one major factor influencing the adoption of RD12 in the intermittent and late season drought environment. The following area discusses economic concept and model of technology adoption.

\section{ANALYTICAL FRAMEWORK}

Several of adoption studies have focused on farm and farmer characteristics with little attention to the characteristics of the varieties (Feder et al., 1985). Doss (2006) emphasized the advantage of micro-level crosssectional analysis to understand farmer preferences, growing conditions in specific areas and what varietal characteristics are important to farmers. Recent studies accentuated farmer perceptions of varietal traits and their influences on the adoption behavior (Adesina and Zinnah, 1993; Adesina and Seidi, 1995; Adesina and Baidu-Forson, 1995; Edmeades et al., 2008; Hintze et al., 2003; Joshi and Pandey, 2006; Wale and Yalew, 2007; Ramasamy et al., 1999), with particular interest in hedonic pricing (Dalton, 2004; Pingali et al., 2001) and revealed preferences of trait valuation (Useche et al., 2009). In this study, farmer preferences for droughttolerant glutinous rice are of particular interest; thus, traits subjectively selected from PVS breeding program are hypothesized to influence the adoption of RD12.

By taking into account production characteristics (example, yield, duration, disease resistance) and consumption characteristics (example, taste), the adoption of glutinous rice variety in the drought-prone areas assumes a utility maximization behavior. An individual farmer (or household), $n$, would obtain a certain level of utility (and/or profit) from each variety alternative, $j$, and will choose one that provides the greatest utility. The true utility that farmer $n$ obtains from variety $j$ is $U_{n j}, j$ $=1,2, \ldots \mathrm{J}$. He will choose variety $i$ if and only if $U_{n i}>U_{n j}$ $\forall j \neq i$. The true utility of farmers is unknown, but varietal traits and perception on traits, labeled $x_{n j} \forall j$, and farm and household characteristics, labeled $s_{n}$, can be observed. Following technology adoption based on technology attributes (Rahm and Huffman, 1984; Adesina and Zinnah, 1993), the representative utility, denoted $V_{n j}$ $=V\left(x_{n j}, s_{n}\right) \forall j$, depends on these observed variables. Since $U_{n j} \neq V_{n j}$, true utility is decomposed as $U_{n j}=V_{n j}+$ $\varepsilon_{n j}$, where $\varepsilon_{n j}$ is assumed to be random. The probability that farmer $n$ chooses variety $i$ (Train, 2009) can be written as:

$$
\begin{aligned}
& P_{n i}=\operatorname{Prob}\left(U_{n i}>U_{n j} \forall j \neq i\right) \\
& =\operatorname{Prob}\left(V_{n i}+\varepsilon_{n j}>V_{n j}+\varepsilon_{n j} \forall j \neq i\right) \\
& =\operatorname{Prob}\left(\varepsilon_{n j}-\varepsilon_{n i}<V_{n i}-V_{n j} \quad \forall j \neq i\right) .
\end{aligned}
$$

The cumulative probably in Equation (1) can be written as:
$P_{n i}=\int_{\varepsilon} I\left(\varepsilon_{n j}-\varepsilon_{n i}<V_{n i}-V_{n j} \forall j \neq i\right) f\left(\varepsilon_{n}\right) d \varepsilon_{n}$.

where $I($.$) equal 1$ when the expression in parentheses is true and 0 otherwise. For this study, we assume that $\varepsilon_{n j}$ is independently, identically distributed extreme value, and the cumulative distribution of $\varepsilon_{n j}-\varepsilon_{n i}$ follows the logistic distribution

$$
F\left(\varepsilon_{n j}-\varepsilon_{n i}\right)=\frac{e^{\varepsilon_{n j}-\varepsilon_{n i}}}{1+e^{\varepsilon_{n j}-\varepsilon_{n i}}}
$$

Given that the logit probability of $V_{n i}$ is sigmoid, the logit model provides appropriate implications for this study. It implies that a small increase in $V_{n i}$ (presumably from improved traits) has little effect on the choice probability when $V_{n i}$ of a variety is either very low or very high, compared to other varieties. The greatest effect of an increase in $V_{n i}$ on the probability of it's being chosen is when the probability is close to 0.5 . For example, in the drought-prone area if the utility from growing a droughttolerant variety $i$ is very low (or very high) compared to other varieties, a small improvement in the droughttolerant trait will have little effect on the probability that a farmer will adopt variety $i$. The change of probability that variety $i$ is adopted from an improved drought-tolerant characteristic will be greatest when there is $50-50$ chance that it is being chosen. Omitting the proof of algebraic manipulation (Train, 2009), the logit choice probabilities of Equation (3) are given as:

$$
P_{n i}=\frac{e^{V_{n i}}}{\sum_{j} e^{V_{n j}}}
$$

The representative utility is specified to be linear in parameters: $V_{n j}=\alpha^{\prime} x_{n j}+\beta^{\prime} s_{n j}$. Thus, a logit choice probability in Equation (4) is defined as:

$P_{n i}=\frac{e^{\alpha^{\prime} x_{n i}+\beta s_{n i}}}{\sum_{j} e^{\alpha^{\prime} x_{n j}+\beta s_{n j}}}$

Parameter estimates from Equation (5) are interpreted as a pairwise comparison between the effects of changes in independent variable on alternative $i$ and the base alternative. The change in probability that farmer $n$ chooses variety $i$ given a change in an observed variable $x_{n i}\left(\right.$ or $\left.s_{n i}\right)$ is:

$\frac{\partial P_{n i}}{\partial x_{n i}}=\frac{\partial\left(\frac{e^{\alpha^{\prime} x_{n i}+\beta s_{n i}}}{\sum_{j} e^{\alpha x_{n j}+\beta s_{n j}}}\right)}{\partial x_{n i}}$

This marginal effect evaluated at the sample mean is given as: 
Table 1. Sampling design and sample size.

\begin{tabular}{|c|c|c|c|c|c|c|}
\hline $\begin{array}{lr}\text { Stage I: } & \text { Rice } \\
\text { production potential } \\
\text { zone }^{*}\end{array}$ & $\begin{array}{l}\text { Stage II: Districts by RD12 } \\
\text { promotion intensity }\end{array}$ & $\begin{array}{c}\begin{array}{c}\text { Total rice } \\
\text { farming } \\
\text { households }\end{array} \\
\end{array}$ & $\begin{array}{l}\text { Population } \\
\text { proportion }\end{array}$ & $\begin{array}{l}\text { Expected } \\
\text { sample } \\
\text { size }\end{array}$ & $\begin{array}{c}\text { Actual } \\
\text { sample } \\
\text { size }\end{array}$ & $\begin{array}{c}\text { Actual } \\
\text { sample } \\
\text { proportion }\end{array}$ \\
\hline A (High) & High: Muang Nongkhai & 11,209 & 0.18 & 44 & 36 & 0.14 \\
\hline \multirow{2}{*}{ B (Medium) } & High: Phon Phisai, Ratanawapi & 19,516 & 0.32 & 77 & 103 & 0.40 \\
\hline & Low: Pak Khat & 3,743 & 0.06 & 15 & 24 & 0.09 \\
\hline \multirow{2}{*}{ C (Low) } & High: So Phisai & 9,704 & 0.16 & 38 & 38 & 0.15 \\
\hline & Low: Fao Rai & 6,749 & 0.10 & 27 & 21 & 0.08 \\
\hline \multirow{2}{*}{ D (Unsuitable) } & Low: Bung Kan & 10,973 & 0.18 & 43 & 36 & 0.14 \\
\hline & Total & 61,894 & 1.00 & 244 & 258 & 1.00 \\
\hline
\end{tabular}

*, Based on rice production potential zoning defined by Nongkhai Rice Research Center (2007).

$\frac{\partial P_{n i}}{\partial x_{n}}=P_{n i}\left(\alpha_{n}-\left(\bar{\alpha}_{n}+\bar{\beta}_{n}\right)\right)$

Where

$\bar{\alpha}_{n}+\bar{\beta}_{n}=\sum_{l} P_{n l} \alpha_{l}+\sum_{k} P_{n k} \beta_{k}$

\section{Data}

The target area for RD12 is the upper Northeast of Thailand where intermittent and late-season drought has been a major constraint on rice productivity. Since the adoption of the new variety is assumed to reveal preferences, the scope of the study area is limited to Nongkhai province in the upper Northeast of Thailand where farmers have access to RD12. Two stage stratified sampling technique was adopted. In the first stage, districts are grouped based on rice production potential zoning defined by Nongkhai Rice Research Center (2007).

The rice production potential zones were classified soil and water conditions combined with climate, top sequence, and farm management. In the second stage, each rice production potential zone is stratified by the intensity of RD12 accessibility. The number of farmers who received RD12 is used as a proxy to capture the extent where RD12 has been promoted. The intensity of RD12 promotion is classified low (less than twenty five farmers who received RD12 seeds during 2003 to 2008) to high (less than 25 farmers who received RD12 seeds during 2003 to 2008). The data are collected from households in seven districts of Nongkhai province in upper Northeast Thailand.

This study assumes a $5 \%$ statistical significant level and $20 \%$ distribution of RD12 in Nongkhai during the presurvey. Adopting Tyfos (1996), the sample size is identified as 244 based on the total of 61,894 rice farming households in seven selected districts (Nongkhai Statistical Office, 2004). The two-stage stratified proportional sampling technique (to total number of rice farm households) was used for the 2009/2010 cropping season. Table 1 shows the actual number of samples in each district. Farmers were interviewed to obtain rice farming information on every plot owned (or rented) by a household, including both during the wet and dry seasons.

\section{EMPIRICAL MODEL}

Based on collected data the four major glutinous rice varieties grown in the sampling area are Hanhg Yi71, RD12, RD10, and RD6. The summary of traits comparison among these varieties is shown in Table 2. A multinomial logit model derived from Equation (5) is estimated for choices of glutinous rice variety $j$ based upon the assumption of a linear utility function. Thus,

$U_{n j}=\sum_{l=1}^{L} \alpha_{n l} x_{j l}+\sum_{k=1}^{K} \beta_{n k} s_{j k}+\varepsilon_{n j}$

In the multinomial logit model, traits and farmers perception on traits $(x)$ includes the yield and taste preference of the new variety (RD12), and the popular high cooking quality rice (RD6), relative to the existing drought-tolerant variety (Hanhg Yi71). The extension of this logit model is to include taste variation associated with observed variables (Train, 2009). We assume that the utility a farmer receives from yield varies depending on the proportion household consumption of glutinous rice to total rice production (CONSUMP). As a result differences in taste could be reflected in the parameter of yield; thus $\beta_{n, y i e l d}=\rho^{*}$ (CONSUMP).

Farm and household characteristics $(s)$ includes the production condition in the drought prone area such as toposequence, access to water, cropping season, recent experience of blast disease, and whether rice production is the main source of income. Access to water is limited in the rainfed areas, particularly during the dry season so these conditions are hypothesized for the adoption of the drought tolerant variety. Aside from drought, blast disease is also the major production problem in sampling areas so the experience of blast disease may also influence the adoption decision. Focusing on the occurrence of RD12 adoption, a binomial logit model is 
Table 2.Traits comparison of popular glutinous rice varieties.

\begin{tabular}{|c|c|c|c|c|c|c|c|c|}
\hline Variety & $\begin{array}{c}\text { Photo- } \\
\text { period } \\
\text { sensitive }\end{array}$ & $\begin{array}{l}\text { Dry } \\
\text { season }\end{array}$ & $\begin{array}{l}\text { Harvest } \\
\text { time }\end{array}$ & $\begin{array}{c}\text { Appropriate } \\
\text { for upper } \\
\text { terrain } \\
\end{array}$ & $\begin{array}{l}\text { Drought- } \\
\text { tolerant }\end{array}$ & $\begin{array}{c}\text { Potential } \\
\text { yield } \\
\text { (ton/ha) }\end{array}$ & Cooking quality & $\begin{array}{l}\text { Blast } \\
\text { tolerant }\end{array}$ \\
\hline Hanhg Yi71 & Yes & No & Nov. 4 & Yes & Drought escape & 3.16 & Soft/chewy & Yes \\
\hline RD12 & Yes & No & Nov. 7-17 & Somewhat & Drought escape & 3.26 & Good, soft/chewy & Somewhat \\
\hline RD10 & No & Yes & 130 days & No & No & 4.12 & Soft & Somewhat \\
\hline RD6 & Yes & No & Nov. 21 & No & Yes & 4.16 & $\begin{array}{l}\text { Very good, } \\
\text { soft/aromatic }\end{array}$ & Susceptible \\
\hline
\end{tabular}

Source: Rice knowledge bank, Rice Department, 2009.

Table 3. Description of variables in choice models.

\begin{tabular}{|c|c|}
\hline \multicolumn{2}{|l|}{ Dependent variable } \\
\hline VARIETY & Glutinous rice variety: Hanhg Yi71, RD6, RD10, RD12 \\
\hline ADOPT & RD12 adoption: 1 if adopt, 0 otherwise. \\
\hline \multicolumn{2}{|c|}{ Independent variables } \\
\hline \multicolumn{2}{|c|}{ Traits and Perception on Traits, $X_{I}$} \\
\hline YIELD & Rice yield (kg/rai) \\
\hline CONSUMP*YIELD & Proportion household consumption of glutinous rice to total rice production * YIELD \\
\hline PRICE & Output price (baht/kg) \\
\hline RD12TASTE & $\begin{array}{l}\text { Farmer perception of RD12 taste: } 1 \text { if farmer thought RD12 has better cooking quality than } \\
\text { Hahngyi71, } 0 \text { otherwise }\end{array}$ \\
\hline RD6TASTE & $\begin{array}{l}\text { Farmer perception of RD } 6 \text { taste: } 1 \text { if farmer thought RD } 6 \text { has better cooking quality than } \\
\text { Hahngyi71, } 0 \text { otherwise }\end{array}$ \\
\hline RD12HARVEST & $\begin{array}{l}\text { Farmer perception of the ease to harvest RD12: } 1 \text { if farmer thought RD12 is easier to } \\
\text { harvest than Hahngyi71, } 0 \text { otherwise }\end{array}$ \\
\hline RD12PLANTING & $\begin{array}{l}\text { Farmer perception of the ease to transplant RD12: } 1 \text { if farmer thought RD12 is easier for } \\
\text { crop establishment than Hahngyi71, } 0 \text { otherwise }\end{array}$ \\
\hline \multicolumn{2}{|c|}{ Farm and household characteristics, $S_{k}$} \\
\hline CONSUMP & Proportion household consumption of glutinous rice to total rice production \\
\hline TOPOSEQUENCE & Toposequence of rice production plot: 1 if upper sloping terrain, 0 otherwise. \\
\hline WATER & Access to water source: 1 if irrigated or availability of other water resources, 0 otherwise. \\
\hline SEASON & Cropping season: 1 if dry season, 0 otherwise \\
\hline BLASTEXP & $\begin{array}{l}\text { Experience of blast disease: } 1 \text { if farmer experience blast disease in the past five years, } 0 \\
\text { otherwise }\end{array}$ \\
\hline MAININC & Main income source: 1 if rice is major source of income, 0 otherwise. \\
\hline
\end{tabular}

1 ha $=6.25$ rai.

estimated ( 1 if adopted, 0 if not adopted). Since RD12 is photoperiod-sensitive, the binomial logit model of RD12 adoption includes only the wet season. Farmers' acceptance of RD12 is hypothesized be influenced mainly by trait perceptions of RD12 relative to Hanhg Yi71 - the existing drought tolerant variety. Table 3 lists all variables of the choice models.

\section{RESULTS AND DISCUSSION}

Tables 4 to 6 show the summary of glutinous rice varieties grown in the study areas. Based on four hundred and forty four plots, RD12 and RD6 are the most preferred varieties (about 35\% individually), followed by Hanhg Yi71 and RD10, respectively. Both RD12 and RD6 are photoperiod-sensitive and have good cooking quality, compared to the others. San Pah Tawng and RD4 were other glutinous rice varieties found in this area, but they are not popular.

The two varieties together accounted for less than $2 \%$. This probably is because San Pah Tawng and RD4 have 
Table 4. Glutinous rice varieties grown in Nongkhai province, 2009/2010.

\begin{tabular}{lcc}
\hline Variety & No. of plots & Percentage \\
\hline Hanhg Yi71 & 97 & 21.85 \\
RD12 & 155 & 34.91 \\
RD10 & 26 & 5.86 \\
RD6 & 159 & 35.81 \\
RD4 & 6 & 1.35 \\
San Pah Tawng & 1 & 0.23 \\
Total & 444 & 100.00 \\
\hline
\end{tabular}

Table 5. Glutinous rice varieties in Nongkhai province by toposequence, 2009/2010*.

\begin{tabular}{lcccc}
\hline \multirow{2}{*}{ Variety } & \multicolumn{2}{c}{ Lower terrain } & \multicolumn{2}{c}{ Upper terrain } \\
\cline { 2 - 5 } & No. of plots & Percentage & No. of plots & Percentage \\
\hline Hanhy Yi71 & 7 & 3.52 & 90 & 37.82 \\
RD12 & 34 & 17.09 & 121 & 50.84 \\
RD10 & 14 & 7.04 & 12 & 5.04 \\
RD6 & 144 & 72.36 & 15 & 6.30 \\
Total & 199 & 100.00 & 238 & 100.00 \\
\hline
\end{tabular}

*Excluding RD4 and San Pah Tawng.

Table 6. Glutinous rice varieties grown in Nongkhai province by cropping season, 2009/2010*.

\begin{tabular}{lcccc}
\hline \multirow{2}{*}{ Variety } & \multicolumn{2}{c}{ Wet } & \multicolumn{2}{c}{ Dry } \\
\cline { 2 - 5 } & No. of plots & Percentage & No. of plots & Percentage \\
\hline Hanhg Yi71 & 96 & 22.97 & 1 & 5.26 \\
RD12 & 154 & 36.84 & 1 & 5.26 \\
RD10 & 11 & 2.63 & 15 & 78.95 \\
RD6 & 157 & 37.56 & 2 & 10.53 \\
\hline Total & 418 & 100.00 & 19 & 100.00 \\
\hline
\end{tabular}

* Excluding RD4 and San Pah Tawng.

poorer cooking quality, are susceptible to blast and are not drought resistant. These findings are similar to the studies by Isvilanonda and Hossain (2000), Gypmantasiri et al. (2003) and Vejpas et al. (2005). Prior to the release of RD12, RD 6 was the most common glutinous rice variety in the rainfed area of Northeast Thailand. Early maturing varieties, including RD15 which has shorter duration than KDML105 (non-glutinous Jasmine rice varieties) were becoming more popular for rainfed lowland area during the wet season (Vejpas et al., 2005). In the upper terrain, RD12 is the most popular variety and accounted for about half of all plots. Hanhg Yi71 which was the recommended variety for upper terrain before the development RD12 is the second most popular (Table 5). In the lower terrain, however, RD6 which has the highest cooking quality is the most popular variety and accounted for over $70 \%$ of all lower terrain production. Rice production in the study area is very limited during the dry season as is evident from Table 6. Again, RD12 and RD6 are the most popular varieties in the wet season. Unsurprisingly compared to RD10 which is nonphotoperiod sensitive; the farmers are less likely to choose Hanhg Yi71, RD12 and RD6 in the dry season.

The parameter estimates of the multinomial logit model are presented in Table 7. More useful results are the estimates of marginal effects presented in Table 8. One of the most interesting findings is that the probability of choosing Hahng Yi71 or RD12 significantly increases by $35 \%$ for upper terrain while there is only about $4 \%$ probably of choosing RD10. The probability of choosing RD6, however, decreases by about $7 \%$ for the upper terrain. This implies that to minimize the risks from late- 
Table 7. Parameter estimates of multinomial logit model (RD10=base).

\begin{tabular}{lcccccc}
\hline \multirow{2}{*}{ Variable } & \multicolumn{2}{c}{ Hanhg Yi71 } & \multicolumn{2}{c}{ RD12 } & \multicolumn{2}{c}{ RD6 } \\
\cline { 2 - 7 } & Parameter $(\boldsymbol{\beta})$ & Std. Err. & Parameter $(\boldsymbol{\beta})$ & Std. Err. & Parameter $(\boldsymbol{\beta})$ & Std. Err. \\
\hline CONST & 0.229 & 1.319 & $2.618^{* *}$ & 1.226 & $3.949^{* *}$ & 1.241 \\
CONSUMP*YIELD & 0.004 & 0.003 & 0.003 & 0.003 & 0.001 & 0.003 \\
RD12 TASTE & -0.103 & 1.000 & -0.159 & 0.981 & -1.781 & 1.130 \\
RD6 TASTE & $3.204^{* *}$ & 1.523 & 1.443 & 1.537 & $3.355^{* *}$ & 1.565 \\
TOPOSEQUENCE & 0.218 & 1.130 & -1.062 & 1.067 & $-4.914^{* *}$ & 1.097 \\
WATER & -0.255 & 0.763 & 0.031 & 0.721 & 0.069 & 0.769 \\
SEASON & $-4.490^{* *}$ & 1.573 & $-6.040^{* *}$ & 1.477 & $-6.997^{* *}$ & 1.348 \\
BLAST & 0.812 & 0.674 & 0.459 & 0.629 & 1.119 & 0.704 \\
MAININC & 0.072 & 0.876 & 0.218 & 0.830 & -0.147 & 0.891 \\
Log likelihood & -342.039 & & & & & \\
Number of plots & 434 & & & & & \\
\hline
\end{tabular}

Table 8. Marginal effects of multinomial logit model.

\begin{tabular}{|c|c|c|c|c|c|c|c|c|}
\hline \multirow{2}{*}{ Variable } & \multicolumn{2}{|c|}{ Hanhg Yi71 } & \multicolumn{2}{|c|}{ RD12 } & \multicolumn{2}{|c|}{ RD6 } & \multicolumn{2}{|c|}{ RD10 } \\
\hline & Coeff & Std. Err. & Coeff & Std. Err. & Coeff & Std. Err. & Coeff & Std. Err. \\
\hline CONSUMP* YIELD & $0.0003^{*}$ & 0.000 & 0.0002 & 0.000 & $-0.00004^{* *}$ & 0.000 & -0.00006 & 0.000 \\
\hline RD12 TASTE & 0.077 & 0.073 & $0.150^{*}$ & 0.089 & $-0.240^{\star *}$ & 0.061 & 0.013 & 0.032 \\
\hline RD6 TASTE & $0.147^{\star}$ & 0.081 & $-0.381^{* *}$ & 0.068 & 0.268 & 0.111 & $-0.034^{\star \star}$ & 0.017 \\
\hline TOPOSEQUENCE & $0.353^{* *}$ & 0.040 & $0.352^{* *}$ & 0.047 & $-0.743^{\star \star}$ & -0.035 & $0.0384^{\star *}$ & 0.017 \\
\hline WATER & -0.046 & 0.056 & 0.022 & 0.079 & 0.024 & 0.082 & 0.0003 & 0.017 \\
\hline SEASON & -0.100 & 0.118 & $-0.440^{* *}$ & 0.072 & $-0.286^{\star *}$ & 0.039 & $0.826^{* *}$ & 0.139 \\
\hline BLAST & 0.026 & 0.055 & -0.114 & 0.070 & 0.109 & 0.067 & -0.021 & 0.024 \\
\hline MAININC & -0.003 & 0.068 & 0.066 & 0.084 & -0.061 & 0.081 & -0.002 & 0.019 \\
\hline
\end{tabular}

${ }^{* *}=$ significance at $5 \%$ level, ${ }^{*}=$ significance at $10 \%$ level.

season drought, the early maturity trait of Hanhg Yi71 and RD12 is the key reason for adopting drought tolerant varieties in the upper sloping terrain.

Another interesting result is the perception that RD12 has better cooking quality than Hanhg Yi71. This increases the probability of adopting RD12 by about $15 \%$ and lowers the probability of adopting RD6 by $2.4 \%$. It suggests that if farmers have a higher preference for the cooking quality of RD12 than for Hanhg Yi71, they will be more likely to adopt RD12 if they believe that RD12 is appropriate for protection against drought. In contrast, the perception that RD6 has a preferred cooking quality than Hahng Yi71 decreases the probability of RD12 by $38 \%$. This is because RD6 is superior for consumption in the existing market. The adoption of new variety RD12 is diminished when farmers have strong cooking preferences for existing varieties.

It is hypothesized that yield could be an important determinant of variety adoption. By allowing variability of yield preference by the proportion of household consumption, it was found that yield as valued by household consumption increases the probability of cultivating Hahng Yi71, but lowers the probability of cultivating RD6. This could be because RD6 is premium glutinous rice that also has high market price. As demand of household consumption increases despite increasing yield, the probability of adopting RD6 decreases. In other words, as household rice demand increases, farmers are more likely to grow Hanhg Yi71 and less likely to grow RD6. Farming in the dry season is possible only for the non-photosensitive variety. Predictably, it increases the probability of growing RD10 (non-photosensitive variety) and decreases the probability of growing RD12 and RD6 (photosensitive varieties).

The results of RD12 adoption excluding dry season from the binomial logit model are shown in Table 9. It is found that for the upper terrain, the probability of adopting RD12 increases by $41 \%$, compared to the lower terrain. Similar implication drawn from this binomial model is that for upper sloping terrain, increasing risk of late-season drought results in a higher likelihood of new early maturity variety. The studies by Joshi and Bauer (2006), 
Table 9. Parameter estimates and marginal effect of binomial logit model of RD12 adoption in wet season.

\begin{tabular}{lcccc}
\hline Variable & Parameter $(\boldsymbol{\beta})$ & Std. Err. & Marginal effect & Std. Err. \\
\hline CONST & $-5.328^{\star *}$ & 1.722 & & \\
YIELD & -0.0004 & 0.001 & -0.00009 & 0.000 \\
PRICE & $0.381^{* *}$ & 0.186 & $0.078^{\star *}$ & 0.038 \\
RD12 TASTE & 0.685 & 0.982 & 0.156 & 0.239 \\
RD12 HARVEST & -0.799 & 0.864 & -0.139 & 0.122 \\
RD12 TRANSPLANT & -2.041 & 1.526 & $-0.248^{* *}$ & 0.087 \\
TOPOSEQUENCE & $2.238^{* *}$ & 0.518 & $0.418^{\star *}$ & 0.079 \\
CONSUMP & $1.434^{* *}$ & 0.671 & $0.295^{\star *}$ & 0.137 \\
Log likelihood & -79.409 & & & \\
Number of plots & 147 & & & \\
\hline
\end{tabular}

${ }^{* *}=$ significance at $5 \%$ level, ${ }^{*}=$ significance at $10 \%$ level.

Nanfumba et al. (2013), and Ward et al. (2013) also suggest that farmer's preferences towards early-maturity or short duration significantly affects rice variety choice in the rainfed area. Because glutinous rice production in this region is important for household consumption, taste preference can be important to the adoption decision. The probability of adopting RD12 increases as the percentage of household consumption increases, perhaps owing to the superior taste and higher potential yield than the existing drought tolerant variety. Similarly, increasing the selling price for rice with the improved cooking quality makes farmers more likely to adopt RD12.

The physical appearance of rice paddy RD12 is more similar Hahng Yi71 (long, skinner, darker yellowish brown) than RD6.Since RD12 is new to the market and not easy to distinguish by appearance, the market price of RD12 is generally the same as Hahng Yi71 although it's cooking quality is similar to RD6. This may suggest that if RD12 were to become more recognized in the market with a higher price, farmers would be more likely to adopt it.

Between two competing drought tolerant varieties: RD12 and Hahng Yi71, RD12 has stronger stalks than Hahng Yi71 so it's believed to be easier to harvest, especially in environment where wind and storms can cause fallen stalks. However, the perception that RD12 is easier to harvest than Hahng Yi71 insignificantly affects the adoption decision of RD12. This is not surprising because from the PVS, tillering is not one of the key preferred traits and our result implies that it may not be important to farmers. Surprisingly, perception of superior cooking quality of RD12, compared to Hahng Yi71, does not affect the probability of RD12 adoption. This could be because in the binomial model, the dry season is excluded and the cooking quality of the new drought tolerant variety is not as important as the drought escape characteristic thus, even if RD12 is superior to Hahng
Yi71 for consumption, the taste alone does not influence the adoption of RD12. The result is similar to Joshi and Bauer (2006) that taste is not significant toward variety choice in the rainfed area of Nepal. It is surprising that the perception that RD12 is easier to transplant than

Hahng Yi71 negatively affects RD12 adoption. It is possible that the ease of transplanting is mistakenly perceived as weaker rooting and germinating and negatively has impacted the adoption.

\section{CONCLUSION AND RECOMMENDATION}

The breeding program of the Rice Department released the new glutinous rice variety RD12, to target the drought problem in Northeast Thailand in 2007. In the RD12 breeding program, farmers' participatory selection was the key in the selection process to ensure the acceptance of the new variety. The major improved characteristics of RD12 which were identified from PVS included early maturity and good cooking quality. RD12 has been promoted in Nongkhai province in the upper Northeast of Thailand where late season drought is a major constraint, particularly for upper terrain. Hahng Yi71 had been the most appropriate variety to target the drought problem prior to the release of RD12 and it has been widely adopted despite its poor cooking quality. Our results show that major traits of RD12 identified by the farmer PVS significantly influences the adoption of the new variety. Farmers in the upper terrain production are more likely to adopt RD12 to minimize the risk from late-season drought. The taste preference towards RD12 compared to existing drought tolerant variety, Hahng Yi71, also significantly increases the probability of RD12 adoption and lowers the probability of adopting RD6, the superior cooking quality variety. However, since RD12 is photoperiod-sensitive, it is less preferred for cultivation in the dry season. The current market still does not 
recognize the quality of the RD12 and often suppresses its price because of its similar physical appearance to the lower quality variety. The result shows that a higher price increases the adoption of RD12; this suggests that when RD12 becomes more recognized in the market and when its price reflects its superior quality, it will be more accepted by farmers. The adoption RD12 has been found to be closely related to farmer perception of its traits. The preferred traits identified by farmer PVS program in rice breeding of RD12 effectively enhance its adoption.

\section{Conflict of Interests}

The author(s) have not declared any conflict of interests.

\section{ACKNOWLEDGEMENTS}

This study is part of the "Measuring the Impact of Rockefeller Foundation's Funding for the Development of Drought-tolerant Rice in Thailand" project supported by the Rockefeller Foundation. The authors greatly appreciate the insights on drought-tolerant rice development in Thailand from the Rice Department breeders: Dr. Boonrat Jongdee, Dr. Grienggrai Pantuwan, and Dr. Suwat Jearakongman. They also thank Mr. Somjai Saleeto from Nongkhai Rice Research Center for information on RD12 extension program; and Ms. Pitchaya Chaiyapoom and Mr. Grianggrai Tubtong for data collection.

\section{REFERENCES}

Adesina AA, Zinnah MM (1993). Technology characteristics, farmers' perceptions and adoption decisions: A Tobit model application in Sierra Leone. Agric. Econ. 9:297-311. http://dx.doi.org/10.1016/01695150(93)90019-9

Adesina AA, Baidu-Forson J (1995). Farmers' perceptions and adoption of new agricultural technology: evidence from analysis in Burkina Faso and Guinea, West Africa. Agric. Econ. 13:1-9. http://dx.doi.org/10.1016/0169-5150(95)01142-8

Adesina AA, Seidi S (1995). Farmers' perceptions and adoption of new agricultural technology: analysis of modern mangrove rice varieties in Guinea Bissau. Q. J. Int. Agric. 34:358-371.

Asian Development Bank (2009). The Economics of Climate Change in Southeast Asia: A Regional Review. [online] Available from: http://www.adb.org/sites/default/files/economics-climate-change-seasia.pdf. [Accessed 10 June 2013].

Bellon MR, Reeves J (Eds.) (2002). Quantitative Analysis of Data from Participatory Methods in Plant Breeding. Mexico, DF: CIMMYT.

Ceccarelli S, Grando S (2007). Decentralized-participatory plant breeding: an example of demand driven research. Euphytica 155:349-360. http://dx.doi.org/10.1007/s10681-006-9336-8

Dalton TJ (2004). A household hedonic model of rice traits: economic values from farmers in West Africa. Agric. Econ. 31:149-159. http://dx.doi.org/10.1016/j.agecon.2004.09.003

Diagn A (2006). Diffusion and adoption of Nerica rice varieties in Côte d'Ivoire. Dev. Econ. 44:208-231. http://dx.doi.org/10.1111/j.17461049.2006.00014.x

Doss C (2006). Analyzing technology adoption using microstudies: limitations, challenges, and opportunities for improvement. Agric.
Econ. 34:207-219. http://dx.doi.org/10.1111/j.1574-0864.2006.00119.x Doward P, Craufurd P, Marfo K, Dogbe W, Bam R (2007). Improving participatory varietal selection processes: participatory varietal selection and the role of informal seed diffusion mechanisms for upland rice in Ghana. Euphytica 155:315-327. http://dx.doi.org/10.1007/s10681-006-9333-y

Edmeades S, Phaneuf DJ, Smale M, Renkow M (2008). Modelling the crop variety demand of semi-subsistence households: bananas in Uganda. J. Agric. Econ. 52:329-349. http://dx.doi.org/10.1111/j.14779552.2007.00153.x

Efisue A, Tongoona P, Derera J, Langyintuo A, Laing M, Ubi B (2008). Farmers' perceptions on rice varieties in Sikasso region of Mali and their implications for rice breeding. J. Agron. Crop. Sci. 194:393-400. http://dx.doi.org/10.1111/j.1439-037X.2008.00324.x

Feder G, Just RE, Zilberman D (1985). Adoption of agricultural innovations in developing countries: a survey. Econ. Dev. Cult. Change. 33:255-297. [online] Available from: http://www.jstor.org/stable/1153228. [Accessed 10 June 2013].

Floch P, Molle F (2007). Marshalling water resources: a chronology of irrigation development in the Chi-Mun river basin, Northeast Thailand. Mekong program on water, environment and resilience, IRD/IWMI. Working Paper.

Gypmantasiri P, Limnirankul B, Muangsuk C (Eds.) (2003). Integration of farmer participatory plant breeding for rainfed lowland rice improvement in North and Northeast Thailand: I Bio-physical and socio-economic characterization of rainfed lowland rice production systems of the North and the Northeast of Thailand. Ubon (Thailand): Ubon Ratchathani Rice Research Center. [online] Available from: http://www.mcc.cmu.ac.th/agsust/publication_SA/Biophysicalsocioeconomic\%20report full\%20paper.pdf. [Accessed 10 June 2014].

Hintze LH, Renkow M, Sain G (2003). Variety characteristics and maize adoption in Honduras. Agric. Econ. 29:307-317. http://dx.doi.org/10.1016/S0169-5150(03)00058-6

International Rice Research Institute (2006). Rice Breeding Course. International Rice Research Institute. [online] Available from: http://www.knowledgebank.irri.org/ricebreedingcourse/bodydefault.ht m\#Participatory_Variety_Trials_For_Rainfed_Rice_Cultivar_Evaluati on.htm. [Accessed 20 October 2013].

International Rice Research Institute (2010). Rough rice production and yield. In World Rice Statistics. International Rice Research Institute. [online] Available from: http://ricestat.irri.org:8080/wrs/. [Accessed 20 June 2013].

Isvilanonda S, Hossain M (2000). Thailand's Rice Economy and Constraints to Increasing Production. Paper presented at the IRRIICAR International Workshop on Constraints to Increasing Rice Production in Asia: Insights from a Study on Farmers' Perceptions, Hyderabad, India, 7-9 June, 2000.

Jongdee B (2003). Designing a national breeding program for developing drought tolerant rainfed lowland varieties: the Thailand experience. In KS Fischer, R Lafitte, S Fukai, G Atlin and B Hardy (Eds.), Breeding Rice for Drought- prone Environments. Los Baños: Int. Rice Res. Institute, pp. 64-69.

Jongdee B, Pantuwan G, Fukai S, Fischer K (2006). Improving drought tolerance in rainfed lowland rice: an example from Thailand. Agric. Water. Manage. 80:225-240. http://dx.doi.org/10.1016/j.agwat.2005.07.015

Jongdee S, Mitchell, JH, Fukai S (1997). Modeling approach for estimation of rice yield reduction due to drought in Thailand. In $S$ Fukai, M Cooper and J Salisbury (Eds.), Breeding Strategies for Rainfed Lowland Rice in Drought-prone Environments. Canberra: Austrian Centre for International Agricultural Research, pp. 65-73.

Joshi GR, Bauer S (2006). Farmers' choice of the modern rice varieties in the rainfed ecosystem of Nepal. J Agric. Rural. Dev. Trop. 107:129-138. [online] Available from: http://www.jarts.info/index.php/jarts/article/view/127/110. [Accessed 10 June 2014].

Joshi GR, Pandey S (2006). Farmer's perceptions and adoption of modern rice varieties in Nepal. Q. J. Int. Agric. 45:171-186.

Kamoshita A, Babu RC, Boopathi NM, Fukai S (2008). Phenotypic and genotypic analysis of drought-resistance traits for development of rice 
cultivars adapted to rainfed environments. Field. Crop. Res. 109:123. http://dx.doi.org/10.1016/j.fcr.2008.06.010

Manzanilla DO, Paris TR, Vergara GV, Ismail AM, Pandey S, Labios RV, Tatlonghari GT, Acda RD, Chi TTN, Duoangsila K, Siliphouthone I, Manikmas MOA, Mackill DJ (2011). Submergence risks and farmers' preferences: implications for breeding Sub1 rice in Southeast Asia. Agric. Syst. 104:335-347. http://dx.doi.org/10.1016/j.agsy.2010.12.005

Mongkolsawat $\mathrm{C}$, Thirangoon $\mathrm{P}$, Suwanweramtorn R, Karladee N, Paiboonsank S, Champathet P (2001). An evaluation of drought risk area in Northeast Thailand using remotely sensed data and GIS. Asian. J. Geoi. 1:33-43.

Morris ML, Bellon MR (2004). Participatory plant breeding research: opportunities and challenges for the international crop improvement system.

Euphytica

136:21-34. http://dx.doi.org/10.1023/B:EUPH.0000019509.37769.b1

Nanfumba D, Turyahabwe N, Ssebuliba J, Kakuru W, Kaugule J, Omio S, Samuka M (2013). Participatory identification of farmer acceptable improved rice varieties for rain-fed lowland ecologies in Uganda. Afr. Crop. Sci. J. 21:683-691. [online] Available from: http://www.ajol.info/index.php/acsj/article/view/98439/87716. [Accessed 20 June 2014]

Nongkhai Rice Research Center (2007). Rice Production Potential Zoning in Nongkhai. Khonkaen: Khonkaen Printing.

Nongkhai Rice Research Center (2013). Nongkhai Province: Knowledge Management Corner for Rice Production. Nongkhai Rice Research Center. [online] Available from: http://nki.brrd.in.th/km/index.php?option=com_content\&view=article\&i $d=45$. [Accessed 20 June 2014].

Nongkhai Statistical Office (2004). Rice Production Area, Villages, and Households by District.

Office of Agricultural Economics of Thailand (2011). Area, yield and total output of rice in Rice Production Statistics, 2010/11. [online] Available from: http://www.oae.go.th/ewt_news.php?nid=9704 [Accessed 20 June 2014]

Pingali PL, Rozelle SD, Gerpacio R (2001). The farmer's voice in priority setting: a cross-country experiment in eliciting technological preferences. Econ. Dev. Cult. Change 49:591-609. http://dx.doi.org/10.1086/452517

Pantuwan G, Jongdee B, Jearakongman S, others (2006). Integration of farmer participatory plant breeding for rainfed lowland rice improvement in North and Northeast. Unpublished report, Ubonratchathani: Rice Department. a copy of this report is on file with the authors. (in Thai)

Prapertchob P, Bhandari H, Pandey S (2007). Economic costs of drought and rice farmers' drought-coping mechanisms in Northeast Thailand. In S Pandey, H Bhandari, B Hardy, (Eds.), Economic costs of drought and rice farmers' coping mechanisms: a cross-country comparative analysis. Los Baños: International Rice Research Institute, pp. 113-148.

Rahm MR, Huffman WE (1984). The adoption of reduced tillage: the role of human capital and other variables. Am. J. Agric. Econ. 66:405413. http://dx.doi.org/10.2307/1240918

Ramasamy C, Bantilan CS, Elangovan S, Asokan M (1999). Perceptions and adoption decisions of farmers in cultivation of improved pearl millet cultivars - a study in Tamil Nadu. Indian. J. Agric. Econ. 54:139-154.

Rasabandit S, Jaisil P, Atlin G, Vera Cruz C, Jongdee B, Banterng P (2006). Participatory variety selection (PVS) to assess farmer preferences of traditional glutinous rice varieties in the Lao PDR. Khon Kaen Agric. 34:128-141.
Rice Department (2009). Registered Rice Varieties of Thailand Database. Bureau of Rice Research and Development. [online] Available from: http://www.brrd.in.th/rvdb/ (in Thai) [Accessed 20 October 2013].

Saleeto S, Jumpaget R, Gasemrat C, others (2009). RD12 (Nong Khai $80)$ rice variety. Thai. Rice. Res. J. 3:5-20.

Snapp S (2002). Quantifying farmer evaluation of technologies: the mother and baby trial design. In MR Bellon, J Reeves (Eds.), Quantitative Analysis of Data from Participatory Methods in Plant Breeding. Mexico, DF: CIMMYT.

Thai Meteorological Department (2012). The assessment of rainfall impact on crops in Thailand. August- September, 2012. 10. Meteorological Department. (in Thai) [online] Available from: http://www.tmd.go.th/climate/climate.php?FileID $=10$. [Accessed 20 October 2013].

Thai Meteorological Department. (2010). Climate variability and climate change projection. Technical Document No. 551-524-01-2010. Climatological Center, Meteorological Department. (in Thai) [online] Available from: http://www.tmd.go.th/info/climate_future.pd. [Accessed 20 October 2013].

Train KE (2009). Discrete Choice Methods with Simulation. Cambridge: Cambridge University Press. http://dx.doi.org/10.1017/CBO9780511805271

Tshewang S, Ghimiray M (2010). Participatory variety selection: increasing rice varietal diversity. Bhu. J. RNR. 6:1-10. [online] Available http://www.corrb.gov.bt/images/RNR\%20Journals/RNR\%20Journal\% 20of\%20Bhutan\%202010.pdf . [Accessed 20 June 2014].

Tyfos P (1996). Sampling Methods for Applied Research: Text and Cases. New York: Wiley.

Useche P, Barham BL, Foltz JD (2009). Integrating technology traits and producer heterogeneity: a mixed-multinomial model of genetically modified corn adoption. Am. J. Agric. Econ. 91:444-461. http://dx.doi.org/10.1111/j.1467-8276.2008.01236.x

Vejpas C, Bousquet F, Naivinit W, Trébuil G, Srisombat N (2005). Companion modeling and multi-agent systems for integrated natural resource management in Asia. In B François, T Guy, H Bill (Eds.), Metro Manila: IRRI, 141-163.

Wale E, Yalew A (2007). Farmers' variety attribute preferences: implications for breeding priority setting and agricultural extension policy in Ethiopia. Afr. Dev. Rev. 19:379-396. http://dx.doi.org/10.1111/j.1467-8268.2007.00167.x

Ward PS, Ortega DL, Spielman DJ, Singh V (2013). Farmer Preferences for Drought Tolerance in Hybrid versus Inbred Rice: Evidence from Bihar, India. IFPRI Discussion Paper 01307. December 2013. International Food Policy Research Institute. CGIAR Research Program on Policies, Institutions and Markets. [online] Available from: http://www.ifpri.org/sites/default/files/publications/ifpridp01307.pdf [Accessed 15 June 2014]

Witcombe JR, Petre R, Jones S, Joshi A (1999). Farmer participatory crop improvement. IV. The spread and impact of a rice variety identified by participatory varietal selection. Exp. Agric. 35:471-487. http://dx.doi.org/10.1017/S0014479799354090

Wurzinger M, Solkner J, Iniguez L (2011). Important aspects and limitations in considering community-based breeding programs for low-input smallholder livestock systems. Small Ruminant Res. 98:170-175. http://dx.doi.org/10.1016/j.smallrumres.2011.03.035 